\title{
Production of exopolymer particles by marine bacterioplankton under contrasting turbulence conditions
}

\author{
Karen E. Stoderegger, Gerhard J. Herndl* \\ Department of Biological Oceanography, Netherlands Institute for Sea Research (NIOZ), PO Box 59, 1790 AB Den Burg, \\ Texel, The Netherlands
}

\begin{abstract}
It has recently been shown that marine bacterioplankton release copious amounts of capsular material as 'semi-labile' to 'refractory' dissolved organic carbon (DOC) into the ambient water. The fate of this bacterioplankton-derived DOC remains largely unknown. Here we investigate the capability of this bacterial-derived capsular DOC to coagulate to exopolymer particles under contrasting turbulence regimes. Under high turbulence, fewer but larger particles $(>2 \mu \mathrm{m}$ in diameter) were detected, while the total exopolymer particle-mass $(>0.2 \mu \mathrm{m})$ was higher under stagnant conditions. Under stagnant conditions most of the bacterial-derived particles remained in the size-class between 0.2 and $2 \mu \mathrm{m}$. The production rate of exopolymer particles was estimated to amount to about 4 amol $\mathrm{C}$ cell $^{-1} \mathrm{~h}^{-1}$, representing about $25 \%$ of the previously estimated bacterioplankton DOC release of about $15 \mathrm{amol} \mathrm{C} \mathrm{cell}^{-1} \mathrm{~h}^{-1}$ Considering that bacterioplarikton represent the largest living surface in the ocean, the release and subsequent coagulation of bacterioplankton-derived capsular DOC might be an important, thus far largely neglected mechanism of exopolymer particle formation in the ocean.
\end{abstract}

KEY WORDS: Particle formation - Bacterioplankton - Exopolymer - Elzone particle counter · Alcian Blue Toluidine Blue Turbulence.DOM.Colloidal

\section{INTRODUCTION}

Bacterioplankton play an active role in the oceanic carbon flux, on the one hand converting dissolved organic carbon (DOC) into particulate organic carbon (POC) as bacterial biomass and $\mathrm{CO}_{2}$ (Azam et al. 1983) and, on the other hand releasing copious amounts of semi-labile to refractory DOC into the ambient water (Brophy \& Carlson 1989, Stoderegger \& Herndl 1998). Generally, the fate of this bacterioplankton-derived DOC is largely unknown. Since natural DOC tends to spontaneously coagulate (Chin et al. 1998), one might speculate that this bacterial-derived DOC coagulates along the size continuum of organic matter (Heissenberger et al. 1996a), eventually forming exopolymer particles.

About $45 \%$ of the glucose incorporated into bacterioplankton is channeled into capsular material (Stoder-

•Addressee for correspondence. E-mail: herndl@nioz.nl egger \& Herndl 1998). This capsular material is constantly released by metabolically active bacteria into the water column, amounting to $25 \%$ of the respired C, and is largely resistant to further bacterial degradation (Stoderegger \& Herndl 1998). The released DOC consists primarily of high molecular weight material composed of highly hydrated polysaccharides (Heissenberger et al. 1996b). Since most of the inactive bacteria do not have a polysaccharide capsule, it is assumed that active bacteria are either continuously renewing components of the capsule, or that the specific binding sites at the cell membrane are losing their ability to fix the polysaccharide fibrils once the cells become dormant or inactive (Heissenberger et al. 1996b). Supporting the latter assumption, starvation of a marine Pseudomonas sp. strain was found to increase the viscosity of the medium due to the release of capsular material (Wrangstadh et al. 1990).

Despite these recent findings, the major source of exopolymers in the ocean is assumed to be phyto- 
plankton derived (Kepkay 1994). Dissolved polysaccharides of phytoplankton origin coagulate in the water column, forming transparent exopolymer particles (TEP) (Alldredge et al. 1993, Kiørboe \& Hansen 1993). Theoretically, particle size should determine sedimentation velocity to a large extent and indirectly, the nutritive value of the particle (Jackson et al. 1997). The measured sedimentation rates, however, are higher than predicted by models (Jackson 1995). This discrepancy could be explained by the collision of sedimenting particles with these TEP, which leads to the formation of larger, more rapidly sedimenting particles.

TEP are stainable with Alcian blue (copper-phthalocyanin with 4 methylene-tetramethyl-cisothiouroniumchloride side chains), a hydrophilic cationic dye that complexes with anionic carboxyl or halfester-sulfate groups of acidic polymers (Passow \& Alldredge 1995). TEP abundance ranges from 30 to $5000 \mathrm{TEP} \mathrm{m}^{-1}$ and from 3 to $>500 \mu \mathrm{m}$ in diameter in coastal regions (Alldredge et al. 1993, Schuster \& Herndl 1995, Mari \& Kiørboe 1996), and decreases by 4 orders of magnitude from coastal to oceanic environments (Alldredge et al. 1993). Even at $1400 \mathrm{~m}$ depth TEP are present in low numbers (Passow \& Alldredge 1994). These TEP are thought to be formed via cationic bridging between polysaccharide fibrils (Alldredge et al. 1993, Passow \& Alldredge 1994).

However, since bacteria comprise the largest living surface in the world's ocean, bacterioplankton capsular material released into the ambient water (Stoderegger \& Herndl 1998) might also contribute significantly to the oceanic DOC pool and after coagulation, to the TEP pool. Only recently, evidence showed that bacterioplankton might be a more prominent source for oceanic DOC than previously assumed. Tanoue et al. (1996) found that porin, a cell wall protein of gramnegative bacteria, occurs ubiquitously in the ocean. McCarthy et al. (1998) reported that bacterial cell wall material (derived from the peptidoglycan layer) constitutes a major source of dissolved organic nitrogen (DON) and Stoderegger \& Herndl (1998) have shown that polysaccharide fibrils originating from the bacterial capsule are fueling the oceanic DOC pool. Thus, there is now evidence that a quantitatively significant pool of bacterial-derived DOC and DON is present in oceanic waters and potentially available for exopolymer particle formation.

Based on this recently emerging notion, the aim of the present study is (1) to quantify the production of exopolymer particles by bacterioplankton grown in seawater dilution cultures and (2) to compare these production rates with the concentration of exopolymer particles found in coastal North Sea waters and elsewhere. Based on previous work, we assumed that the polysaccharide fibrils released by bacterioplankton originate from the capsule and coagulate to exopolymer particles. Since this coagulation of single fibrils to particles might be dependent on the turbulence regime in the water, we performed these experiments under 2 contrasting turbulence conditions. Different polysaccharide-specific stains and different techniques for quantification were used to enumerate and size the exopolymer particles, since Jackson et al. (1997) showed that the number as well as the size of particles depends to a larger extent on the method used.

\section{MATERIAL AND METHODS}

Experimental set-up to determine the production of exopolymer particles by bacterioplankton under turbulent versus stagnant conditions. Fresh seawater from the coastal North Sea was taken with rinsed (0.1 $\mathrm{N} \mathrm{HCl)} 201$ carboys from the NIOZ pier at high tide between February and April 1998. To establish seawater dilution cultures for bacterioplankton (Ammerman et al. 1984), $1.8 \mathrm{l}$ of $0.2 \mu \mathrm{m}$ (Millipore, polycarbonate) filtered seawater was inoculated with $200 \mathrm{ml}$ of $0.8 \mu \mathrm{m}$ filtered seawater (Millipore, polycarbonate) and incubated under 2 contrasting turbulence conditions in the dark at $16^{\circ} \mathrm{C}$ for $11 \mathrm{~d}$. Turbulence was generated by a laboratory shaker (New Brunswick Scientific Edison; $120 \mathrm{rpm}$ ). To prevent growth of protists in the dilution cultures, a mixture of eukaryotic inhibitors $\left(100 \mathrm{mg} \mathrm{l}^{-1}\right.$ colchicine and $200 \mathrm{mg} \mathrm{l}^{-1}$ cycloheximide) was added. These inhibitors had no significant effect on bacterial growth as determined in previous experiments (Heissenberger \& Herndl 1994, see also Sherr et al. 1986). Four experiments were performed under turbulent and stagnant conditions, respectively. Each treatment consisted of duplicate $2 \mathrm{l}$ flasks and 1 formaldehyde-fixed control $(0.5 \% \mathrm{v} / \mathrm{v}$ final conc. $)$. The development of the abundance and size distribution of particles was followed in the different treatments by daily sampling during the exponential phase of bacterial growth and, after bacteria reached the stationary phase, at $2 \mathrm{~d}$ intervals.

To determine the abundance and size of bacteria and particles, $200 \mathrm{ml}$ subsamples were collected from each flask and transferred into combusted $\left(450^{\circ} \mathrm{C}\right.$ for $4 \mathrm{~h}$ ) glass flasks for enumeration under the epifluorescence microscope and for analysis with an Elzone particle counter as described below.

Additionally, freshly collected unfiltered seawater was sampled from the NIOZ pier at high tide and analyzed for bacterial and exopolymer particle abundance and size for comparison with the exopolymer particles obtained in the seawater cultures.

Colorimetric quantification of exopolymer particles stained with Alcian Blue. To quantify the exopolymer 
particle-mass, a $50 \mathrm{ml}$ subsample was filtered onto a polycarbonate filter as described above, rinsed with $0.2 \mu \mathrm{m}$ filtered distilled water and subsequently stained with $0.5 \mathrm{ml}$ of an aqueous solution of Alcian Blue $10.02 \%$ in $0.06 \%$ acetic acid, $\mathrm{pH} 2.5,0.2 \mu \mathrm{m}$ filtered, Passow \& Alldredge 1995). Immediately after staining the exopolymer particles on the filter, the filter was transferred into a $25 \mathrm{ml}$ glass vial and soaked in $6 \mathrm{ml}$ of $80 \% \mathrm{H}_{2} \mathrm{SO}_{4}$ for $10 \mathrm{~h}$. During this period, the vial was gently agitated 3 to 5 times. The absorption of the solution was measured in a $1 \mathrm{~cm}$ glass cuvette at $787 \mathrm{~nm}$ wavelength against distilled water treated in the same way as the samples (Passow \& Alldredge 1995). As described by Passow \& Alldredge (1995), the concentration of TEP $\left(C_{\mathrm{TEP}}\right)$ is expressed as gum xanthan equivalent ( $\mu \mathrm{g} \mathrm{l}^{-1}$ ) by

$$
C_{\mathrm{TEP}}=\left(E_{787}-C_{787}\right) \times\left(V_{1}\right)^{-1} \times f_{\mathrm{x}}
$$

where $E_{787}$ is the absorption of the sample, $C_{787}$ is the absorption of the blank, $V_{i}$ is the volume of water (in liters) filtered and $f_{x}$ is the calibration factor in $\mu g \quad A$ standard was prepared with gum xanthan (Sigma, G1253) and $f_{\mathrm{x}}$ determined according to

$$
f_{\mathrm{x}}=W \times\left(\left[e^{2} t_{787}-C_{787}\right] \times V_{\mathrm{s1}}^{-1}\right)^{-1}
$$

where $W$ is the dry weight of the gum xanthan $\left(\mathrm{Hg} \mathrm{l}^{-1}\right)$, est $_{787}$ its average absorption, $C_{787}$ the absorption of the blank, and $V_{s t}$ the volume of the standard (in liters) filtered. Average absorption of filter blanks varied between 0.065 and 0.085 , which is well within the range reported by Passow \& Alldredge (1995), while the average dry weight of gum xanthan retained on the filter was higher in our study, probably due to the smaller pore size we used $(0.2 \mu \mathrm{m}$ instead of $0.4 \mu \mathrm{m}$ as used by Passow \& Alldredge 1995).

Determination of particle abundance and size using the Elzone particle counter. A $100 \mathrm{ml}$ subsample from each treatment was gently shaken and filtered through a $50 \mu \mathrm{m}$ mesh and $200 \mu \mathrm{l}$ subsamples were analyzed in triplicate with an Elzone particle counter (112 LTNACSD/ADC S/N 72471) using a $48 \mu \mathrm{m}$ aperture. The particle size measured ranged between 2 and $19 \mu \mathrm{m}$. Previous experiments indicated no significant influence of gently shaking the beakers before counting, while intensive stirring altered the particle size spectrum significantly (data not shown). Consequently, the measurements were performed without further stirring of the subsamples to avoid alterations in the size spectrum of the particles.

The particle size spectrum was described using the power relation

$$
\mathrm{d} N / \mathrm{d}\left(d_{\mathrm{p}}\right)=\mathrm{k} d_{\mathrm{p}}^{-\beta}
$$

where $\mathrm{d} N$ is the number of particles per unit volume in the size range $d_{p}$ to $d_{p}+d\left(d_{p}\right)$ (Mari \& Burd 1998). The constant $\mathrm{k}$ depends on the slope and the concentration of particles while $\beta$ describes the size distribution of particles. Increasing $\beta$ indicates decreasing abundance of large particles. The 2 constants were determined by regression of $\log \left[\mathrm{d} N / \mathrm{d}\left(d_{p}\right)\right]$ versus $\log \left(d_{p}\right)$ (Mari \& Burd 1998)

Enumeration of exopolymer particles stained with Toluidine Blue. For enumeration of Toluidine Bluestained particles, $30 \mathrm{ml}$ subsamples were filtered onto polycarbonate filters (Millipore, $0.2 \mu \mathrm{m}$ pore size, supported by cellulose-nitrate filters) with a suction pressure of $<150$ mbar. Thereafter, the filtration funnel was rinsed with $0.5 \mathrm{ml}$ of $0.2 \mu \mathrm{m}$ filtered $0.1 \mathrm{M}$ acetate buffer ( $\mathrm{pH}=5.6$ ) followed by staining with $0.5 \mathrm{ml}$ of $0.2 \mu \mathrm{m}$ filtered Toluidine Blue solution $(0.1 \%$ Toluidine Blue in $0.1 \mathrm{M}$ acetate buffer, $\mathrm{pH}=5.6$ ). After rinsing the filter 3 times with the acetate buffer solution, the filter was placed onto the frosted Cyto-Clear-Slide (Poretics, Corp.), covered with a drop of immersion oil (Olympus, nd $=1.516$ at $23^{\circ} \mathrm{C}$ ) and a coverslip and stored in the dark at $4^{\circ} \mathrm{C}$ for up to $3 \mathrm{~d}$. Cyto-Clearslides were used to avoid interference of the polycarbonate filters when viewing the particles under transillumination (Logan et al. 1994). The lower limit of particle size recorded for Toluidine Blue-stained particles was $19 \mu \mathrm{m}$. Blanks were prepared from a $30 \mathrm{ml}$ subsample filtered twice through $0.2 \mu \mathrm{m}$ polycarbonate filters to remove exopolymer particles and then filtering the water again through a polycarbonate filter, followed by staining and rinsing the filter as described above. The number of exopolymer particles stained with Toluidine Blue was always very low in the blanks (usually less than $30 \%$ of the total number of Toluidine Blue-stainable particles $<19 \mu \mathrm{m}$ and $0 \%$ in the size range $>19 \mu \mathrm{m}$ which was the lower size limit used for enumeration. At least 20 images per filter and treatment were analyzed for the abundance and size distribution at a magnification of $125 \times$ using transmission light microscopy (Zeiss, Axioplan) connected to an image analysis system (Leica, Quantiment 570) (Mari \& Burd 1998). The size distribution of exopolymer particles was determined by calculating the equivalent spherical diameter (ESD) and the volume of the exopolymer particles. As image analysis systems tend to underestimate small-size particles (Jackson et al. 1997), the data obtained by microscopy and image analysis (particles $>19 \mu \mathrm{m}$ ESD) were combined with those of the Elzone particle counter (particle size range: 2 to $19 \mu \mathrm{m}$ ESD).

Bacterial enumeration. Twenty $\mathrm{ml}$ subsamples were withdrawn from the seawater dilution cultures and fixed with $0.2 \mathrm{ml}$ of $0.2 \mu \mathrm{m}$ filtered concentrated formalin. Bacterial abundance was enumerated on 1 to $5 \mathrm{ml}$ samples after staining the bacteria with Acridine Orange (Hobbie et al. 1977) and filtering them onto 
black polycarbonate filters (Millipore, $0.2 \mu \mathrm{m}$ pore size). Bacterial enumeration was performed with an epifluorescence microscope (Zeiss, Axioplan) connected to the image analysis system as described above. Bacterial abundance was determined at a magnification of $1250 \times$. A minimum of 10 images per sample was counted or at least 300 bacteria.

Terminology used for bacterial-derived exopolymer particles detected by the different methods. Throughout the 'Results' and 'Discussion' we used the term transparent exopolymer particles (TEP) for particles stained with Alcian Blue and retained by polycarbonate filters of $0.2 \mu \mathrm{m}$ pore size (>0.2 $\mu \mathrm{m}$ ESD). The term Elzone-particles (Elz-P) is used for particles detected by the Elzone particle counter (2 to $19 \mu \mathrm{m}$ ESD) and the term Toluidine Blue-particles (TB-P) stands for exopolymer particles $>19 \mu \mathrm{m}$ ESD stained with Toluidine Blue and enumerated under the transmission microscope.

\section{RESULTS}

\section{Time course of bacterial abundance and bacterial-derived TEP mass}

In the seawater cultures, the development of bacterial abundance was similar in the 2 contrasting turbulence regimes (Fig. 1). The exponential growth phase of bacteria started within $24 \mathrm{~h}$, the increase in Alcian Blue-stained TEP mass, however, was not detectable

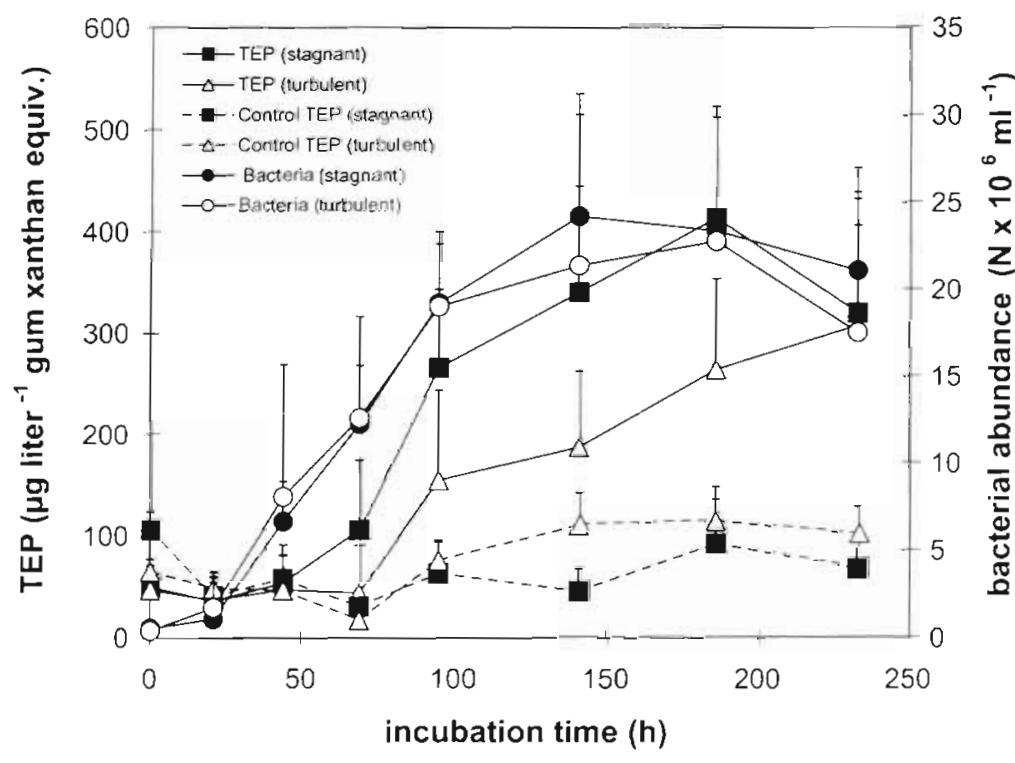

Fig. 1 Time course of bacterial abundance and TEP mass $(>0.2 \mu \mathrm{m})$ expressed as gum xanthan equivalents under turbulent and stagnant conditions and in the corresponding ablotic controls. Symbols represent means 1 SD of 4 experiments
Table 1. Average $\beta$ and $\log (\mathrm{k})$ of the regression lines fitted to the curves of the particle distribution determined for Elz-P and TB-P under stagnant and turbulent conditions, respectively $\left(\mathrm{r}^{2}=0.86 \pm 0.06 ; \mathrm{n}=140\right)$. The formula used to calculate $\beta$ and $\log (\mathrm{k})$ is given in 'Material and methods' Numbers represent means $\pm \mathrm{SD}$, the number of measurements is given in parentheses (the first 2 time points are excluded from the analysis). Elz-P (Elzone particles) were counted by the Elzone particle counter (size range 2 to $19 \mu \mathrm{m}$ ESD), TB-P are exopolymer particles $>19 \mu \mathrm{m}$ enumerated under the microscope after staining with Toluidine Blue

\begin{tabular}{|ccccc}
\hline \multirow{2}{*}{ Treatment } & \multicolumn{2}{c}{ Biotic } & \multicolumn{2}{c}{ Abiotic control } \\
& $\beta$ & $\log (\mathrm{k})$ & $\beta$ & $\log (\mathrm{k})$ \\
\hline Stagnant & $2.72 \pm 0.78$ & $3.28 \pm 0.61$ & $2.12 \pm 0.44$ & $2.66 \pm 0.34$ \\
& $(48)$ & $(48)$ & $(22)$ & $(22)$ \\
Turbulent & $2.02 \pm 0.38$ & $2.79 \pm 0.29$ & $1.81 \pm 0.32$ & $2.60 \pm 0.27$ \\
& $(48)$ & $(48)$ & $(22)$ & $(22)$ \\
& & &
\end{tabular}

until 70 and 92 h under stagnant and turbulent conditions, respectively (Fig. 1). Thereafter, TEP mass increased steadily and reached significantly higher concentrations (Wilcoxon; $\mathrm{p}=0.0025 ; \mathrm{n}=20$ ) under stagnant than under turbulent conditions. In individual experiments, maximum TEP concentrations ranged between 300 and $800 \mu \mathrm{g} \mathrm{l}^{-1}$ gum xanthan equivalents in the stationary phase of the stagnant treatment. No significant difference (Wilcoxon; $p=0.182 ; n=15$ ) in the TEP concentrations was detectable between the stagnant and turbulent treatments for the abiotic controls (Fig. 1). The TEP concentrations in these 2 abiotic controls remained stable throughout the incubation.

\section{Time course of exopolymer particle abundance measured by the Elzone particle counter (Elz-P) and Toluidine Blue-staining (TB-P)}

Combining the Elz-P volume estimates (size range: 2 to $19 \mu \mathrm{m}$ ) with the microscopic counts of $T B-P$ (size range: $>19 \mu \mathrm{m})$, a rapid increase in particle abundance, especially in the size range of 2 to $4 \mu \mathrm{m}$, was detectable under stagnant conditions after $48 \mathrm{~h}$ (Fig. 2) while under turbulent conditions, only a slight increase in particle abundance, especially during the exponential growth phase, was detectable. Under stagnant conditions, the number of particles was significantly higher than under turbulent conditions (Wil$\operatorname{coxon}_{i} p=0.0072 ; n=16$ ). In the stationary phase of bacterial growth, particle abun- 


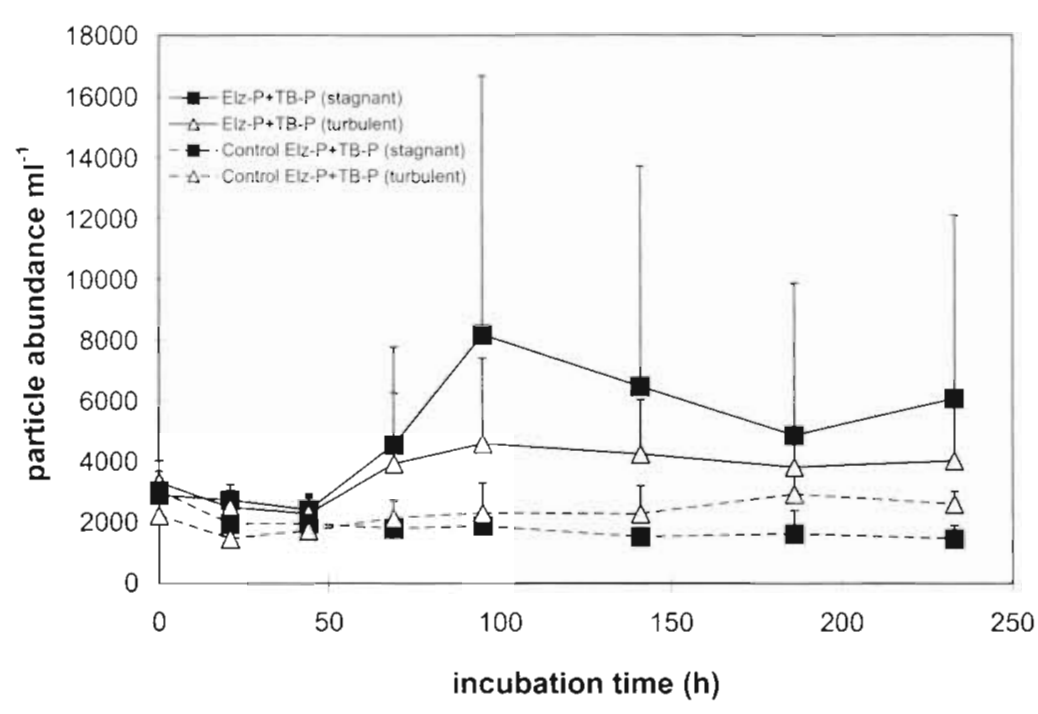

Fig. 2. Development of the abundance of exopolymer particles (Elz-P + TB$\mathrm{P})$ in seawater cultures determined by enumeration with the Elzone particle counter (for particles with an ESD of 2 to $19 \mu \mathrm{m}$, Elz-P) and under the microscope after Toluidine Blue-staining (for particle ESD $>19 \mu \mathrm{m}$, TB-P). Symbols represent means $+1 \mathrm{SD}$ of 4 experiments particles in the control experiments (Table 1). Both parameters $(\beta, \log \mathrm{k})$ exhibited highly significant differences between stagnant and turbulent conditions and between the treatments and their corresponding abiotic control (Friedman; $p<0.01$ at least; $n=44$ in all cases $)$.

\section{Exopolymer particle abundance in the coastal North Sea waters}

Coastal North Sea waters contained a much higher number of exopolymer particles than the seawater cultures. When counted with the Elzone particle counter, Elz-P could not be separated from other non-living particles also present in high abundance. The TEP-mass expressed as gum xanthan equivalents was $1162 \pm$ $204 \mu \mathrm{g} \mathrm{l}^{-1}$; mean Elz-P + TB-P abundance was $1.1 \pm 0.3 \times 10^{5} \mathrm{mll}^{-1}(\mathrm{n}=2)$, or in terms of volume, $7.02 \pm 2.25 \mathrm{~mm}^{3} \mathrm{l}^{-1}$. For the

dance decreased again. Generally, there was no significant formation of exopolymer particles detectable in the formalin-fixed controls (Fig. 2).

Total volume of exopolymer particles (Elz-P + TB-P) was more than 10 times higher under turbulent than under stagnant conditions (Wilcoxon; $\mathrm{p}=0.0004 ; \mathrm{n}=$ 16) in the stationary phase (Fig. 3). Therefore, total particle volume showed the opposite trends as compared to the development of the TEP-mass (Fig. 1). The Elz-P + TB-P volume was significantly higher in the biotic treatments (Wilcoxon; $\mathrm{p}<0.02$ at least, $\mathrm{n}=15$ ) than in the respective controls.

The parameter $\beta$ characterizing the distribution of Elz-P + TB-P indicated that there were fewer particles in the smaller size range under turbulent than under stagnant conditions (Table 1). For stagnant conditions, $\beta$ ranged between 1.4 and 4.5 and between 1.3 and 2.9 in the corresponding abiotic control. $\beta$ for turbulent conditions ranged between 1.1 and 2.8 in the biotic treatment and from 1.0 to 2.9 in the corresponding control (Table 1). Log $(k)$, characterizing the concentrations of the particles, ranged from 2.1 to 4.6 and 1.9 to 3.3 under stagnant conditions and in the corresponding abiotic control, respectively, and under turbulent conditions from 2.2 to 3.4 and 1.8 to 2.9 in the biotic and abiotic treatment, respectively, indcating much lower concentrations of
2 sampling dates, $\log (k)$ were 5.1 and 4.7 and $\beta$ were 3.2 and 2.7 , respectively.

\section{DISCUSSION}

Bacterioplankton release copious amounts of polymeric substances throughout their life stages: when they are metabolically active, via the release of poly-

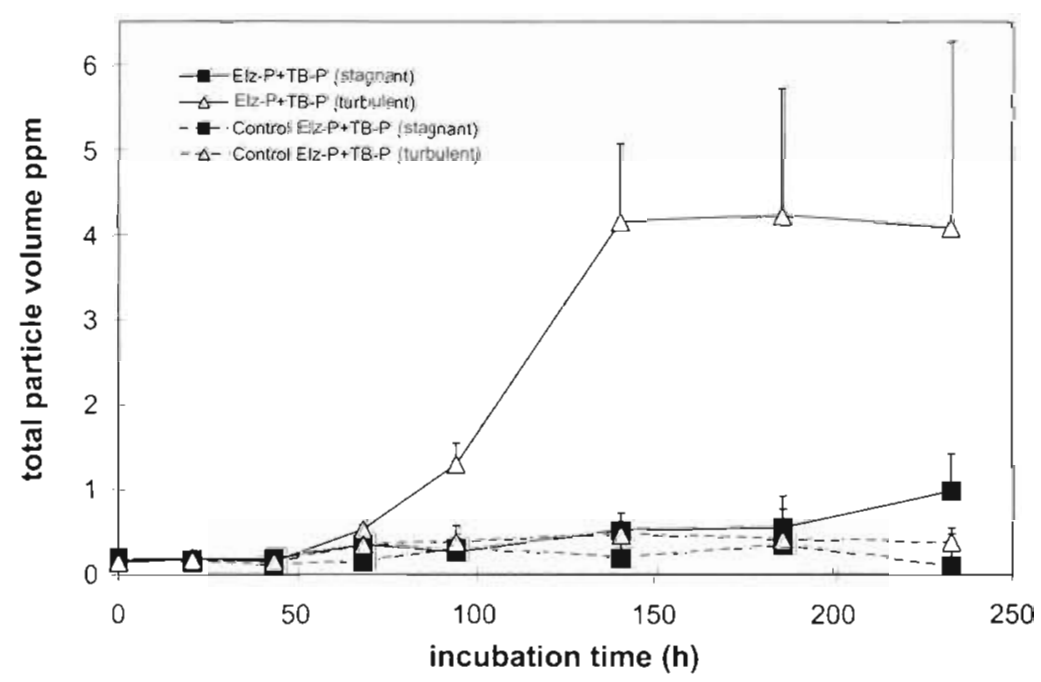

Fig. 3. Development of total particle volume (Elz-P + TB-P) under the 2 different turbulence conditions. Total particle volume was calculated from the enumeration with the Elzone particle counter (for particles with an ESD of 2 to $19 \mu \mathrm{m}$, Elz-P) and under the microscope using Toluidine Blue-staining for particles with ESD $>19 \mu \mathrm{m}$. Symbols represent means +1 SD of 4 experiments 
saccharide fibrils from the permanently renewed capsule (Stoderegger \& Herndl 1998) and during bacterial decay via the release of intracellular material (Shibata et al. 1997). In the latter study, it has been shown that viral lysis of bacteria leads to the formation of about 20 submicron particles bacterium ${ }^{-1}$ (particle size range: 0.4 to $0.7 \mu \mathrm{m}$ ). As described previously (Alldredge et al. 1993), most of the stainable particles were discrete, highly deformable films, strings or sheets of mucus rather than distinct particles. If small volumes of water are filtered, larger particles are too low in number to allow statistical analysis, and mucus layers are too thin to allow accurate quantification. Filtration of larger volumes of water, however, leads to thick mucus layers, again making quantification difficult. Due to these methodological problems inherent to the quantification of exopolymer particles, we applied a combination of several techniques.

Besides the frequently used Alcian-Blue staining of exopolymer particles, we also used Toluidine Bluestaining and focused on larger exopolymer particles with this approach. Using this stain and enumerating TB-P > $19 \mu \mathrm{m}$ ESD with the image analysis system, we were able to largely avoid problems associated with exopolymer particle counting using other stains. It has been reported that either parts of an aggregate or whole particles are occasionally not stainable with Alcian Blue due to the lack of negatively charged polysaccharides (Logan et al. 1994). Another potential bias might be introduced if particles exhibiting insufficient contrast after staining are viewed against a bright white field during microscopic examination (Logan et al. 1994).

The smaller-sized Elz-P (2 to $19 \mu \mathrm{m}$ ESD), were also the most abundant exopolymer particles. As Elz-P abundance was always high in the 2 to $4 \mu \mathrm{m}$ size range, it can be assumed that exopolymer particles $<2 \mu \mathrm{m}$ not enumerated with this technique were highly abundant as well. This assumption is also supported by the fact that TEP-mass expressed as gum xanthan equivalents (size range $>0.2 \mu \mathrm{m}$ ) is much higher under stagnant than under turbulent conditions (Fig. 1). Under turbulent conditions, aggregation to larger particles might be facilitated, leading to the observed high particle volume (of the size range $>2 \mu \mathrm{m}$ ESD) as indicated in Fig. 3. A number of studies show that small colloids (5 to $200 \mathrm{~nm}$ ) are the most abundant particles in seawater, reaching concentrations of $10^{9}$ particles ml $^{-1}$ (Koike et al. 1990, Wells \& Goldberg 1991, 1993).

\section{Particle formation and size distribution}

The volume of particles (Elz-P + TB-P; $>2 \mu \mathrm{m}$ ) was much higher under turbulent than under stagnant con- ditions (Fig. 3). During the remarkable increase in volume, the abundance of these particles remained almost constant (Fig. 2) indicating coagulation and aggregation. The higher total TEP-mass (>0.2 $\mu \mathrm{m}$; Fig. 1) and particle abundance (>2 $\mu \mathrm{m}$, Fig. 2) under stagnant conditions and at the same time, higher particle volume in the $>2 \mu \mathrm{m}$ size fraction under turbulent conditions indicate that newly-released colloidal organic matter probably coagulates much faster to particles $>2 \mu \mathrm{m}$ ESD under turbulent than under stagnant conditions. With the increase in diameter of an aggregate, the porosity increases as well (Jackson et al. 1997). This variable porosity results in apparent sizes of particles not related to the particle mass in the same way as the diameter of a solid sphere is related to its volume and mass (Jackson et al. 1997). The porosity of exopolymer particles might be responsible for an increase in the measured size of particles when collapsed on a filter relative to when they are suspended in the water (Passow \& Alldredge 1995) ultimately leading to an overestimation of the actual volume of an exopolymer particle (Fig. 3). The smaller size ranges of particles, however, might be underestimated due to the condensation of exopolymer particles during staining (McCave 1984).

Particle formation is dependent on various factors such as particle stickiness and density, shape of the particle, turbulence, microbial activity as well as other physical and chemical factors (McCave 1984). Brownian motion is the main collision mechanism for particles from the submicron to $\leq 8 \mu \mathrm{m}$ diameter range at all turbulence intensities, while shear is the major mechanism to increase collision between particles with a diameter $>1.7 \mu \mathrm{m}$ (McCave 1984). In mixed surface waters, the particle size tends to be evenly distributed with a slope, $\beta$, of about 3 (McCave 1984, Jackson et al. 1997). Samples from the North Sea exhibited a $\beta$ of 2.7 to 3.5 , whereas $\beta$ tends to be lower under laboratory conditions, especially under turbulence. The formation of larger particles reduces particle abundance consequently resulting in lower values of $\mathrm{k}$ under turbulence. Based on our experiments, it is evident that bacteria release relatively high amounts of exopolymers, which undergo spontaneous coagulation to form microscopically visible particles.

\section{Bacterial contribution and production of exopolmer particles}

Based on the ratio between bacterioplankton abundance and the number of exopolymer particles determined in the stationary phase of our experiments (ratio: $2 \times 10^{-4}[\mathrm{Elz}-\mathrm{P}+\mathrm{TB}-\mathrm{P}] \mathrm{cell}^{-1}$ ), the bacterioplankton contribution to the standing stock of exopolymer 
particles can be roughly estimated. Taking themean abundance of bacteria $\left(5 \times 10^{6} \mathrm{ml}^{-1}\right)$ and exopolymer particles (Elz-P + TB-P: $11 \times 10^{4}$ $\mathrm{ml}^{-1}$ ) determined for the coastal North Sea (this study), we estimate that bacteria contribute 1 to $2 \%$ to the total number of exopolymer particles $>2 \mu \mathrm{m}$ in the coastal North Sea. When basing our estimations on the mass of acidic polymers (TEP) and on the volume of Elz-P + TB-P, we arrive at an estimated bacterioplankton contribution of 4 to $5 \%$ and 2 to $9 \%$, respectively.

Based on the data shown in Figs. 1 to 3, production rates of exopolymer particles by bacteria can be calculated. Mean TEP production amounts to $0.11 \pm 0.03 \mathrm{fg}$ gum xanthan equivalents cell ${ }^{-1} \mathrm{~h}^{-1}$ under stagnant conditions and $0.07 \pm 0.02 \mathrm{fg}$ gum xanthan equivalents cell ${ }^{-1} \mathrm{~h}^{-1}$ under turbulent conditions (Table 2). Based on microscopic enumeration of TB-P combined with the enumeration of Elz-P, the production of these exopolymer particles is 5 times higher under stagnant than under turbulent conditions (Table 2). The production estimates on a particle volume basis; however, is $10 \times$ lower under stagnant than under turbulent conditions (Table 2).

\section{Exopolymer particles and carbon flux}

Mari \& Burd (1998) calculated the carbon content of an exopolymer particle originating from exudates of the diatom Thalassiosira weissfloggui using the formula TEP-C $=0.25 \times 10^{6} \times r^{\mathrm{D}} \mu \mathrm{g} \mathrm{C} \mathrm{TEP}{ }^{-1}$, where $r$ is the radius of the particle and $\mathrm{D}$ the fractal dimension. When this equation (with $\mathrm{D}=2.55$ ) is applied to our combined measurements of TB-P + Elz-P ( $r=0.5$ ESD), an exopolymer particle $\mathrm{C}$-production rate is obtained amounting to $4.5 \mathrm{amol} \mathrm{C} \mathrm{cell}^{-1} \mathrm{~h}^{-1}$ and $29 \mathrm{amol} \mathrm{C} \mathrm{cell}^{-1}$ $\mathrm{h}^{-1}$ for stagnant and turbulent conditions, respectively. Jackson et al. (1997) found fractal dimensions for marine particles to range from 2.26 to 2.36 , while lower values for the fractal dimensions are usually obtained for more porous structures like marine snow. Since we know that the particles we detected are derived from bacterial capsular material consisting of $>95 \%$ water, this material can be considered as highly porous. Mari \& Kiorboe (1996) used a fractal dimension of 1.5 and Engel \& Schartau (1999) found that fractal dimensions in aggregates are always $<2$. Assuming therefore a fractal dimension of 2, we arrive at an exopolymer particle-C production rate of $2.6 \mathrm{amol} \mathrm{C} \mathrm{cell-1} \mathrm{h}^{-1}$ for stagnant and 5.1 amol $\mathrm{C} \mathrm{cell}{ }^{-1} \mathrm{~h}^{-1}$ for turbulent conditions (Table 2). This estimate is in good agreement with release estimates of bacterial-derived capsular material of $15 \mathrm{amol} \mathrm{C} \mathrm{cell}{ }^{-1} \mathrm{~h}^{-1}$ (Stoderegger \& Herndl 1998).
Table 2. Mean bacterioplankton production of exopolymer particles cell $^{-1} \mathrm{~h}^{-1}$ expressed as TEP-mass $(>0.2 \mu \mathrm{m})$, Elz-P + TB-P abundance total particle volume (Elz-P + TB-P) and carbon content of the particles $(>2 \mu \mathrm{m})$ based on the enumeration of Elz-P + TB-P. All the data are derived from Figs. 1 to 3 . For each experiment the production rate was calculated by subtracting the mean of the duplicates at the beginning of the exponential phase from the values obtained at the end of the exponential phase. Numbers represent means \pm SD for 4 determinations

\begin{tabular}{|c|c|c|}
\hline \multirow[t]{2}{*}{ Particle production } & \multicolumn{2}{|c|}{ Condition } \\
\hline & Stagnant & Turbulent \\
\hline $\begin{array}{l}\text { TEP mass } \\
\text { (fg gum xanth. equiv. cell }{ }^{-1} h^{-1} \text { ) }\end{array}$ & $0.11 \pm 0.03$ & $0.072 \pm 0.02$ \\
\hline $\begin{array}{l}\text { Elz-P }+ \text { TB-P abundance } \\
\left(\mathrm{N} \times 10^{-6} \text { particles cell }{ }^{-1} \mathrm{~h}^{-1}\right)\end{array}$ & $7.2 \pm 6.1$ & $1.3 \pm 0.6$ \\
\hline $\begin{array}{l}\text { Elz-P + TB-P volume } \\
\left(\mu m^{3} \text { cell }^{-1} h^{-1}\right)\end{array}$ & $0.0002 \pm 0.0001$ & $0.002 \pm 0.0003$ \\
\hline $\begin{array}{l}\text { Particle C-production } \\
(\text { amol C cell } \\
\left.\text { (am } \mathrm{h}^{-1}\right)\end{array}$ & 2.6 & 5.1 \\
\hline
\end{tabular}

Thus, about 17 to $33 \%$ of the bacterial-derived capsular polysaccharides further coagulate to form bacterialderived exopolymer particles.

\section{CONCLUSION}

In this study, we have shown that bacterioplanktonderived DOC coagulates to form exopolymer particles. These bacterial-derived exopolymer particles appear to have more characteristics of hydrated gels than solid particles and aggregate faster under turbulent conditions than under stagnant conditions. Converting the measured formation rate of exopolymer particles into C-units, 2.6 to 5.1 amol exopolymer particle-C cell $^{-1}$ $\mathrm{h}^{-1}$ is produced, depending on the turbulence condition

Acknowledgements. We thank W. Klein-Breteler for his introductions on the Elzone particle counter and G. J. van Noort and $\mathrm{H}$. Witte for help on the image analysis system. Financial support was provided by the Commission of the European Community (TMR contract MAS3-CT97-5046) and by the Austrian Bureau for Foreign Studies (08/J1014) to K.E.S. This work is in partial fulfillment of the requirements for a $\mathrm{PhD}$ degree from the University of Vienna by K.E.S. This is contribution no. 3411 of the Netherlands Institute for Sea Research.

\section{LITERATURE CITED}

Alldredge AL, Passow U, Logan BE (1993) The existence, abundance, and significance of large transparent exopolymer particles in the ocean. Deep-Sea Res I 40:1131-1140 
Ammerman JW, Fuhrman JA, Hagström $\AA$, Azam F (1984) Bacterioplankton growth in seawater: I. Growth kinetics and cellular characteristics in seawater cultures. Mar Ecol Prog Ser 18:31-39

Azam $F$, Fenchel $T$, Field $J$, Gray $G$, JS, Meyer-Reil LA, Thingstad $F$ (1983) The ecological role of water-column microbes in the sea. Mar Ecol Prog Ser 10:257-263

Brophy JE, Carlson DJ (1989) Production of biologically refractory dissolved organic carbon by natural seawater microbial populations. Deep-Sea Res 36:497-507

Chin WC, Orellana MV, Verdugo P (1998) Spontaneous assembly of marine dissolved organic matter into polymer gels. Nature 391:568-572

Engel A, Schartau M (1999) Influence of transparent exopolymer particles on sinking velocity of Nitzschia closterium aggregates. Mar Ecol Prog Ser 182:69-76

Heissenberger A, Herndl GJ (1994). Formation of high molecular weight material by free-living marine bacteria. Mar Ecol Prog Ser 111:129-135

Heissenberger A, Leppard GG, Herndl GJ (1996a) Ultrastructure of marine snow. Il. Microbiological considerations. Mar Ecol Prog Ser 135:299-308

Heissenberger A, Leppard GG, Herndl GJ (1996b) Relationship between the intracellular integrity and the morphology of the capsular envelope in attached and freeliving marine bacteria. Appl Environ Microbiol 62: $4521-4528$

Hobbie JE, Daley RJ, Jasper S (1977) Use of nuclepore filters for counting bacteria by epifluorescence microscopy. Appl Environ Microbiol 33:1225-1228

Jackson GA (1995) TEP and coagulation during a mesocosm experiment. Deep-Sea Res II 42:215-222

Jackson GA, Maffione R, Costello DK, Alldredge AL, Logan BE, Dam HG (1997) Particle size spectra between 1 um and $1 \mathrm{~cm}$ at Monterey Bay determined using multiple instruments. Deep-Sea Res I 44:1739-1767

Kepkay PE (1994) Particle aggregation and the biological reactivity of colloids. Mar Ecol Prog Ser 109:293-304

Kiørboe T, Hansen JLS (1993) Phytoplankton aggregate formation: observations of patterns and mechanisms of cell sticking and the significance of exopolymeric material. J Plankton Res 15:993-1018

Kiørboe T, Lundsgaard C, Olesen M, Hansen JLS (1994) Aggregation and sedimentation processes during a spring phytoplankton bloom: a field experiment to test coagulation theory. J Mar Res 52:297-323

Koike I, Hara S, Terauchi K, Kogure K (1990) Role of submicrometer particles in the ocean. Nature 345:242-244

Logan BE, Grossart HP, Simon M (1994) Direct observation of

Editorial responsibility: Otto Kinne (Editor),

Oldendorf/L whe Germany phytoplankton, TEP and aggregates on polycarbonate filters using brightfield microscopy. J Plankton Res 16: $1811-1815$

Mari X, Burd A (1998) Seasonal size spectra of transparent exopolymeric particles (TEP) in a coastal sea and comparison with those predicted using coagulation theory. Mar Ecol Prog Ser 163:63-76

Mari X, Kiorboe T (1996) Abundance, size distribution and bacterial colonization of transparent exopolymeric particles (TEP) during spring in the Kattegat. J Plankton Res 18:969-986

McCarthy MD, Hedges JI, Benner R (1998) Major bacterial contribution to marine dissolved organic nitrogen. Science 281:231-234

MCCave IN (1984) Size spectra and aggregation of suspended particles in the deep ocean. Deep-Sea Res 31:329-352

Passow U, Alldredge AL (1994) Distribution, size and bacterial colonization of transparent exopolymer particles (TEP) in the ocean. Mar Ecol Prog Ser 113:185-198

Passow U, Alldredge AL (1995) A dye-binding assay for the spectrophotometric measurement of transparent exopolymer particles (TEP). Limnol Oceanogr 40:1326-1335

Passow U, Alldredge AL, Logan BE (1994) The role of particulate carbohydrate exudates in the flocculation of diatom blooms. Deep-Sea Res 41:335-357

Schuster S, Herndl GJ (1995) Formation and significance of transparent exopolymeric particles in the northern Adriatic Sea. Mar Ecol Prog Ser 124:227-236

Sherr BF, Sherr EB, Andrew TL, Fallon RD, Newell SY (1986) Trophic interactions between heterotrophic protozoa and bacterioplankton in estuarine water analyzed with metabolic inhibitors. Mar Ecol Prog Ser 32:169-179

Shibata A, Kogure K, Koike I, Ohwada K (1997) Formation of submicron colloidal particles from marine bacteria by viral infection. Mar Ecol Prog Ser 155:303-307

Stoderegger KE, Herndl GJ (1998) Production and release of bacterial capsular material and its subsequent utilization by marine bacterioplankton. Limnol Oceanogr 43:877-884

Tanoue E, Ishii M, Midorikawa T (1996) Discrete dissolved and particulate proteins in oceanic waters. Limnol Oceanogr 41:1334-1343

Wells ML, Goldberg ED (1991) Occurrence of small colloids in sea water. Nature 353:342-344

Wells ML, Goldberg ED (1993) Colloid aggregation in seawater. Mar Chem 41:353-358

Wrangstadh $M$, Szewzyk U, Östling J, Kjelleberg S (1990) Starvation-specific formation of a peripheral exopolysaccharide by a marine Pseudomonas sp., strain 59. Appl Environ Microbiol 56:2065-2072

Submitted: March 15, 1999; Accepted: June 3, 1999

Proofs received from author(s): November 1, 1999 